\title{
Impact of Different Durations of Fasting on Intestinal Autophagy and Serum Metabolome in Broiler Chicken
}

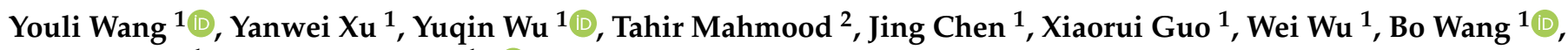 \\ Yuming Guo ${ }^{1}$ and Jianmin Yuan ${ }^{1, *(D)}$ \\ 1 State Key Laboratory of Animal Nutrition, College of Animal Science and Technology, China Agricultural \\ University, Beijing 100193, China; wangylwy@163.com (Y.W.); xu17801115275@163.com (Y.X.); \\ xiaowu333@foxmail.com (Y.W.); chenjing96518@163.com (J.C.); GXRFY0820@163.com (X.G.); \\ cau_wesir@163.com (W.W.); wangbo123@cau.edu.cn (B.W.); guoyum@cau.edu.cn (Y.G.) \\ 2 Adisseo Animal Nutrition, Dubai 00000, United Arab Emirates; tahir472@gmail.com \\ * Correspondence: yuanjm@cau.edu.cn; Tel./Fax: +86-10-62732337
}

\section{check for} updates

Citation: Wang, Y.; Xu, Y.; Wu, Y.; Mahmood, T.; Chen, J.; Guo, X.; Wu, W.; Wang, B.; Guo, Y.; Yuan, J. Impact of Different Durations of Fasting on Intestinal Autophagy and Serum Metabolome in Broiler Chicken. Animals 2021, 11, 2183. https:// doi.org/10.3390/ani11082183

Academic Editors: Paweł Konieczka, Dorota Bederska-Łojewska and Velmurugu Ravindran

Received: 16 June 2021

Accepted: 20 July 2021

Published: 23 July 2021

Publisher's Note: MDPI stays neutral with regard to jurisdictional claims in published maps and institutional affiliations.

Copyright: (c) 2021 by the authors. Licensee MDPI, Basel, Switzerland. This article is an open access article distributed under the terms and conditions of the Creative Commons Attribution (CC BY) license (https:// creativecommons.org/licenses/by/ $4.0 /)$.
Simple Summary: Fasting is usually used before metabolizable energy assessment in poultry. Recently, fasting-induced autophagy has been of concern because of the beneficial function of autophagy. In this study, we found that the intestinal autophagy gene Atg7 has a good quadratic fitting with fasting duration. We found that the serum metabolism pathways involved in glycerophospholipid, phenylalanine, GnRH signaling pathways, glycosylphosphatidylinositol anchor biosynthesis, autophagy, and ferroptosis changed with fasting. Furthermore, we found a correlation between intestinal autophagy and serum metabolite PE (18:3(9Z,12Z,15Z)/P-18:0).

Abstract: Fasting-induced autophagy in the intestine is beneficial for body health. This study was designed to explore the relationship between the host metabolism and intestinal autophagy. Broilers were randomly assigned into 48 cages. At 0 (CT), 12 (FH12), 24 (FH24), 36 (FH36), 48(FH48), and $72 \mathrm{~h}$ (FH72) before 09:00 a.m. on day 25, eight cages of birds were randomly allotted to each fasting time point using completely random design, and their food was removed. At 09:00 a.m. on day 25 , the blood and jejunum were sampled for serum metabolome and autophagy gene analyses, respectively. The results showed that the autophagy gene Atg7 has a good quadratic fit with fasting duration $\left(\mathrm{R}^{2}=0.432, p<0.001\right)$. Serum phosphatidylethanolamine (PE) and lyso-PE were decreased in the birds that were fasted for $24 \mathrm{~h}$ or longer. Conversely, the serum phosphatidylcholine (PC) and lyso-PC were increased in the birds that were fasted for $36 \mathrm{~h}$ or longer. Metabolism pathway analysis showed that the serum glycerophospholipid, phenylalanine, and GnRH signaling pathways were downregulated with the extended fasting duration. The serum metabolites involved in glycosylphosphatidylinositol anchor biosynthesis, autophagy, and ferroptosis were upregulated in all of the fasted groups. Correlation analysis showed that serum PE (18:3(9Z,12Z,15Z)/P-18:0) was a potential biomarker for intestinal autophagy. Our findings provide a potential biomarker related to intestinal autophagy.

Keywords: fasting; serum metabolome; broiler chicken; autophagy

\section{Introduction}

Fasting is becoming more popular in the public because of its beneficial effects, such as anti-aging, anti-inflammatory, and body fat loss [1]. Additionally, fasting is also used to empty the gastrointestinal tract before analyzing the energy efficiency of certain feed ingredient in chickens [2-5]. During fasting, AMP-activated protein kinase is activated and inhibits the mechanistic target of rapamycin in order to suppress cell growth and activate autophagy [6]. Then, activated autophagy scavenges cytoplasmic materials for energy production [7] and regulates gut homeostasis [8,9]. It has been reported that anomalous autophagy is associated with inflammatory bowel diseases [10] and impaired 
absorptive enterocytes [8]. What is more, activated intestinal autophagy triggered by fasting protects against TNF-induced apoptosis during chronic colitis and improves life span $[11,12]$. In vitro, it has been reported that the autophagy level varies with fasting durations [13]. However, the autophagy level in the intestine in response to different fasting durations remain unknown.

It has been suggested that 12 to $24 \mathrm{~h}$ of fasting causes a $20 \%$ or more decrease in the serum glucose, and depletion of hepatic glycogen in humans [14]. Consequently, fatty acids, ketone bodies, and amino acids are used as energy sources. Traditionally, blood sampling after overnight fasting ( $\geq 8 \mathrm{~h}$ ) is used to monitor body metabolism in humans [15-17] and chickens alike [18]. However, broiler chickens are fed ad libitum, except for 1 to $4 \mathrm{~h}$ of darkness every day $[19,20]$. As at least $8 \mathrm{~h}$ are needed for emptying the gastrointestinal tract of chickens [21], the broiler's systemic metabolism can be better characterized by a nonfasted serum. Nowadays, the recommendation of non-fasting blood samples for blood profile assessment in humans has been emerged [22]. Previous studies have been reported the influence of 58 to $96 \mathrm{~h}$ of fasting on the host metabolism in humans and mice [23,24]. Serum metabolites have been shown to be involved in digestive function $[25,26]$, which means that serum metabolites may reflect some functions of the intestine. What is more, white blood cells have been recommended to monitor autophagic flux [24]. It is unclear whether there is a metabolite in the serum that is highly correlated with the level of intestinal autophagy.

Liquid chromatography strip-quadrupole mass spectrometry (LC-MS) is regarded as the best choice for vast serum metabolite detection [27]. Therefore, in the present work, we aimed to study the impact of different fasting durations on intestinal autophagy and LCMS-based untargeted serum metabolites. Furthermore, the potential relationship between serum metabolites and intestinal autophagy was explored.

\section{Materials and Methods}

All of the procedures were complied with the Beijing Regulations of Laboratory Animals, and the Laboratory Animal Ethical Committee of China Agricultural University approved this study (no. AW04110202-3).

\subsection{Bird Management}

A total of 240 one-day-old male broiler chickens (Arbor Acres Plus) were obtained from a commercial hatchery and were randomly assigned to cages with five birds in each cage. The broiler chickens were raised on wire net floors and received a lighting program 23L:1D (turn off at 23:00 p.m. and turn on at 24:00 p.m.) on arrival, which was transformed to a new lighting program 20L:4D (turn off at 22:00 p.m. and turn on at 02:00 a.m.) from day 8. The room temperature was initially set at $33^{\circ} \mathrm{C}$ and then gradually decreased according to the age of the birds, until reaching $23^{\circ} \mathrm{C}$ on day 21 . All of the broilers had free access to water and feed. Broiler chickens were fed a standard corn-soybean meal-based diet, as shown in Table 1. Titanium dioxide ( $5 \mathrm{~g}$ per $\mathrm{kg}$ diet) added in the feed to collect digestibility data for other work.

Table 1. Ingredient composition of experimental diet ${ }^{1}$ (as-fed basis).

\begin{tabular}{cc}
\hline Item & Composition \\
\hline Ingredient $(\%)$ & 50.70 \\
Corn & 41.60 \\
Soybean meal $\left(44 \% \mathrm{CP}^{2}\right)$ & 3.30 \\
Soybean oil & 1.35 \\
Limestone & 1.43 \\
Di-calcium phosphate & 0.35 \\
Sodium chloride & \\
\hline
\end{tabular}


Table 1. Cont.

\begin{tabular}{cc}
\hline Item & Composition \\
\hline Vitamins premix ${ }^{3}$ & 0.03 \\
Mineral premix 4 & 0.20 \\
Phytase & 0.02 \\
Choline chloride (60\%) & 0.20 \\
DL-Methionine (98\%) & 0.30 \\
Antioxidant & 0.02 \\
Titanium dioxide & 0.50 \\
Analyzed nutrient content & \\
Gross energy (Mcal/kg) & 4.03 \\
Crude Protein (\%) & 21.99 \\
Ether extract & 6.00 \\
Total starch & 39.12 \\
Calcium (\%) & 1.15 \\
Total phosphorus (\%) & 0.56 \\
\hline
\end{tabular}

${ }^{1}$ Diet is a pellet diet. ${ }^{2} \mathrm{CP}$, crude protein. ${ }^{3}$ The vitamin premix provides the following per $\mathrm{kg}$ of diets, vit amin A (trans-retinyl acetate) 12,500 IU, vitamin D3 $2500 \mathrm{IU}$, vitamin E (DL- $\alpha$-tocopherol) $20 \mathrm{IU}$, vitamin K3 $2.65 \mathrm{mg}$, vitamin B1 $2.00 \mathrm{mg}$, vitamin B2 $6.00 \mathrm{mg}$, vitamin B6 $6.00 \mathrm{mg}$, vitamin B12 $0.03 \mathrm{mg}$, biotin $0.03 \mathrm{mg}$, folic acid $1.25 \mathrm{mg}$, pantothenic acid $12.00 \mathrm{mg}$, and nicotinic acid $50.00 \mathrm{mg}$. ${ }^{4}$ The trace mineral premix provided the following per $\mathrm{kg}$ of diets: $\mathrm{Cu}\left(\mathrm{CuSO}_{4} \bullet 5 \mathrm{H}_{2} \mathrm{O}\right), 8.00 \mathrm{mg}$; $\mathrm{Zn}\left(\mathrm{ZnSO}_{4}\right), 75.00 \mathrm{mg} ; \mathrm{Fe}\left(\mathrm{FeSO}_{4} \bullet \mathrm{H}_{2} \mathrm{O}\right), 80.00 \mathrm{mg} ; \mathrm{Mn}$ $\left(\mathrm{MnSO}_{4} \bullet \mathrm{H}_{2} \mathrm{O}\right), 100.00 \mathrm{mg}$; $\mathrm{Se}\left(\mathrm{Na}_{2} \mathrm{SeO}_{3}\right), 0.30 \mathrm{mg} ; \mathrm{I}(\mathrm{KI}), 0.35 \mathrm{mg} ; \mathrm{Co}\left(\mathrm{CoSO}_{4} \bullet 7 \mathrm{H}_{2} \mathrm{O}\right), 0.50 \mathrm{mg}$.

\subsection{Sample Collection}

On day 21, several cages of birds were selected and weighed to get 48 birds with similar body weights. Then, these 48 birds were randomly divided into 48 cages with one bird per cage. At 0 (CT), 12 (FH12), 24 (FH24), 36 (FH36), 48(FH48), and $72 \mathrm{~h}$ (FH72) before 09:00 a.m. on day 25, eight cages of birds were randomly allotted to each fasting time point using completely random design, and the food was removed (Figure 1). At 09:00 a.m. on day 25 , the blood samples were drawn from all of these birds' wing veins. The birds were then euthanized by intravenous injection of sodium pentobarbitone $(30 \mathrm{mg} / \mathrm{kg})$. Middle jejunum (about $0.25 \mathrm{~cm}$ ) was collected and washed with saline solution, then snap-frozen in liquid nitrogen immediately, and stored at $-80{ }^{\circ} \mathrm{C}$ for mRNA analysis. After $4 \mathrm{~h}$ of routine temperature shelving, the serum was obtained by centrifugation at $3000 \mathrm{~g}$ for $10 \mathrm{~min}$ at $4{ }^{\circ} \mathrm{C}$. Samples of jejunum and serum were stored at $-80^{\circ} \mathrm{C}$ for later analysis.

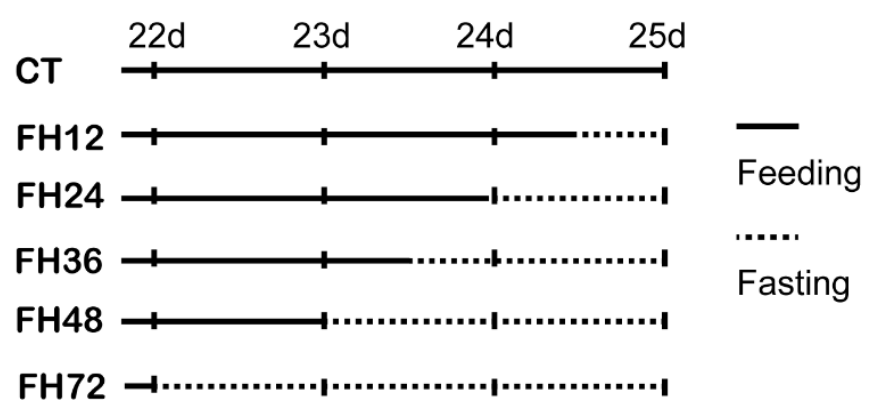

Figure 1. Fasting procedure. CT—birds fed ad libitum; FH12 - birds fasted for 12 h; FH24—birds fasted for 24 h; FH36 - birds fasted for 36 h; FH48_-birds fasted for 48 h.

\subsection{Chemical Analysis}

The feed samples were finely ground and passed through a $40 \mu \mathrm{m}$ strainer. The gross energy in the feed was determined using an oxygen bomb calorimeter (PARR 6400; Parr Instrument Company, Moline, IL, USA) with benzoic acid as the calibration standard. The nitrogen in the feed was determined using the Kjeldahl method (FOSS KT 200 Kjeltec, Hillerod, Denmark) [28], and CP was calculated using 6.25-fold of nitrogen. The crude fat in the feed was determined in double $1 \mathrm{~g}$ samples, packaged into filter-bags (Ankom 
XT4; ANKOM Technology, Macedon, NY, USA) and extracted by petroleum ether at least 50 times, using a Soxhlet extractor for the ether extract analysis. The starch in the feed was analyzed using a total starch assay kit according to the manufacturer's instruction (KSTA; Megazyme, Bray, Wicklow, Ireland). Three technical replicate samples were used for the determination of the total calcium and total phosphorus content of the feed using the permanganate titration method and phosphovanoclonoly beate molecular absorption spectrometric method, respectively.

\subsection{Autophagy-Related Gene Expression}

The total RNA was extracted from the chicken jejunum using RNAiso Plus (9109; TAKARA, Kyoto, Japan). The purity and concentration of the total RNA were measured with a nucleic acid analyzer (Nano-drop 2000, Thermo Fisher Scientific, Waltham, MA, USA) using the 260:280 nm absorbance ratio. The complementary DNAs of chicken Atg7 (Accession no. NM_001030592.1) were amplified with the primer as follows: Atg7 sense, CACTGCGGAACTTCCTGATCTTGG, and Atg7 antisense, CTTGCATGGTCCT GTCTCTGAAGC. According to the manufacturer's instructions, cDNA synthesis was performed using a PrimeScript RT reagent kit with a gDNA eraser. Real-time PCR was conducted on a 7500-fluorescence detection system (Applied Biosystems, Carlsbad, USA) and set as described previously [29]. The mRNA level of Atg7 was normalized against the housekeeping gene $\beta$-actin (accession no. XM_027015741.1, amplified as sense CAACACAGTGCTGTCTGGTGGTAC and antisense CTCCTGCTTGCTGATC CACATCTG) using the $2^{-\Delta \Delta C t}$ method.

\subsection{Blood Serum Preparation}

The blood serum samples stored at $-80^{\circ} \mathrm{C}$ were thawed at room temperature. Then, the samples were analyzed using LC-MS by OE Biotech. Co., Ltd., in Shanghai. Then, $100 \mu \mathrm{L}$ of each sample was added to a $1.5 \mathrm{~mL}$ tube with $10 \mu \mathrm{L}$ of 2-chloro-l-phenylalanine $(0.3 \mathrm{mg} / \mathrm{mL})$ dissolved in methanol as the internal standard, and then vor-texed for $10 \mathrm{~s}$. Subsequently, $300 \mu \mathrm{L}$ of the ice-cold mixture of methanol and acetonitrile $(2 / 1, v / v)$ was added, and the mixtures were vortexed for $1 \mathrm{~min}$, ultrasonicated at an ambient temperature $\left(25^{\circ} \mathrm{C}\right.$ to $28^{\circ} \mathrm{C}$ ) for $10 \mathrm{~min}$, and stored at $-20^{\circ} \mathrm{C}$ for $30 \mathrm{~min}$. The extract was centrifuged at $13,000 \mathrm{rpm}, 4^{\circ} \mathrm{C}$ for $15 \mathrm{~min}$. The supernatants $(200 \mu \mathrm{L})$ from each tube were collected using crystal syringes, filtered through $0.22 \mu \mathrm{m}$ micro-filters, and transferred to LC vials. The vials were stored at $-80^{\circ} \mathrm{C}$ until the LC-MS analysis. Quality control samples were prepared by mixing aliquots of all of the samples to be a pooled sample.

\subsection{Liquid Chromatography-Mass Spectrometry Analysis}

A Shimadzu 30AD UHPLC system fitted with a Q-Exactive quadrupole-Orbitrap mass spectrometer equipped with a heated electrospray ionization source (Thermo Fisher Scientific, Waltham, MA, USA) was used to analyze the metabolic profiling in both the ESI positive and ESI negative ion modes. An ACQUITY UPLC BEH C18 column (1.7 $\mu \mathrm{m}$, $2.1 \times 100 \mathrm{~mm}$ ) was employed in both the positive and negative modes. The binary gradient elution system consisted of (A) water (containing $0.1 \%$ formic acid, $v / v$ ) and (B) acetonitrile (containing $0.1 \%$ formic acid, $v / v$ ), and separation was achieved using the following gradients: $5 \%$ B over $0-2 \mathrm{~min}, 20 \%$ B over $2-24 \mathrm{~min}, 100 \%$ B over $24-28.1 \mathrm{~min}$, and $5 \%$ B over 28.1-30 $\mathrm{min}$. The flow rate was $0.2 \mathrm{~mL} / \mathrm{min}$ and the column temperature was $40^{\circ} \mathrm{C}$. All of the samples were kept at $4{ }^{\circ} \mathrm{C}$ during the analysis. The injection volume was $5 \mu \mathrm{L}$.

The mass range was from $m / z 66.7$ to 1000.5 . The resolution was set at 70,000 for the full MS scans and 17,000 for the HCD MS/MS scans. The collision energy was set at 20, 40 , and $60 \mathrm{eV}$. The mass spectrometer was operated as follows: spray voltage, $3000 \mathrm{~V} \mathrm{(+)}$

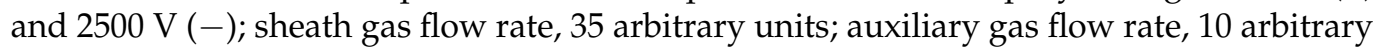
units; and capillary temperature, $320^{\circ} \mathrm{C}$. The QCs were injected at regular intervals (every 10 samples) throughout the analytical run in order to provide a set of data from which the repeatability could be assessed. 


\subsection{Data Preprocessing and Statistical Analysis}

The acquired LC-MS raw data were analyzed by the progenesis QI software (Waters Corporation, Milford, NE, USA) using the following parameters. The precursor tolerance was set to $5 \mathrm{ppm}$, the fragment tolerance was set to $10 \mathrm{ppm}$, and the retention time (RT) tolerance was set to $0.02 \mathrm{~min}$. The internal standard detection parameters were deselected for the peak RT alignment, isotopic peaks were excluded for analysis, the noise elimination level was set at 10.00 , and the minimum intensity was set to $15 \%$ of base peak intensity. The resulting matrix was obtained with three-dimension data sets, including $m / z$, peak RT, and peak intensities, and the RT $-m / z$ pairs were used as the identifier for each ion. The resulting matrix was further reduced by removing any peaks with a missing value (ion intensity $=0$ ) in more than $50 \%$ of the samples. The internal standard was used for data quality control.

Metabolites were identified by progenesis QI (Waters Corporation, Milford, NE, USA) Data Processing Software, based on databases such as http://www.hmdb.ca/; http:/ / www.lipidmaps.org/ and self-built databases (accessed on 6 December 2018). The positive and negative data were combined to get combine data that was imported into the $R$ ropes package. Principle component analysis (PCA) and orthogonal partial least-squaresdiscriminant analysis (OPLS-DA) were carried out to visualize the metabolic alterations among the experimental groups, after mean centering (Ctr) and Pareto variance (Par) scaling, respectively. The Hotelling's T2 region, shown as an ellipse in the score plots of the models, defines the $95 \%$ confidence interval of the modeled variation. Variable importance in the projection (VIP) ranked the overall contribution of each variable to the OPLS-DA model, and those variables with VIP $>1$ were considered relevant for group discrimination.

In this study, the default seven-round cross-validation was applied, with one/seventh of the samples being excluded from the mathematical model in each round, in order to guard against overfitting. The differential metabolites were selected based on the combination of a statistically significant threshold of variable influence on the projection values obtained from the OPLS-DA model and $p$ values from a two-tailed Student's $t$-test on the normalized peak areas, where metabolites with VIP values larger than 1.0, $p$ values less than 0.05 , and fold change over 2 were considered as differential metabolites. MBRole was used for the metabolite pathway enrichment analysis.

The data of the Atg7 gene expression were analyzed by ANOVA and Tukey was used in the post hoc test. Pearson's correlation was used to analyze the correlation between $\mathrm{PE}$ and autophagy gene Atg7 using an R statistical package named Corrplot. The values were means, with SEM represented by vertical bars. Treatments with different letters were significantly different $(p \leq 0.05)$.

\section{Results}

\subsection{Intestinal Autophagy at Different Durations of Fasting}

This study showed that the mRNA level of Atg 7 was significantly $(p<0.05)$ upregulated at every fasting time point, except for $12 \mathrm{~h}$ of fasting (Figure 2). Linear regression did not provide a good fit between the Atg 7 and fasting durations $\left(R^{2}=0.092, p=0.036\right)$, but quadratic fitting provided a good fit $\left(R^{2}=0.432, p<0.001\right)$.

\subsection{PCA and OPLS-DA Analysis of Chicken Serum at Different Durations of Fasting}

The PCA score plots suggested a distinct separation among the different fasting durations (Figure 3A). All of the samples in the score plots of the samples were within the 95\% Hotelling T2 ellipse. The OPLS-DA revealed a clear separation between the non-fasting and fasting groups (Figure 3B-F). The OPLS-DA models indicated that different fasting time points all significantly affected the serum metabolic patterns. 


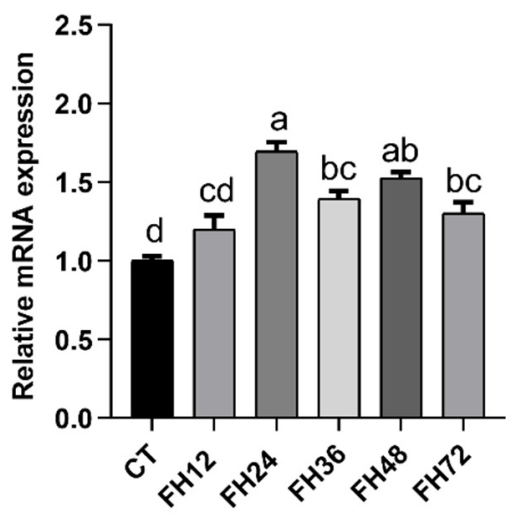

Figure 2. Relative expression of autophagy gene Atg7 at different fasting durations. Data are analyzed by ANOVA and multiple comparisons using the Duncan correction. Values are means $\pm \mathrm{SEM}, n=8$. Labeled means without a common letter are significantly different, $p \leq 0.05$. CT-birds fed ad libitum; FH12 — birds fasted for 12 h; FH24 — birds fasted for 24 h; FH36 — birds fasted for 36 h; FH48 — birds fasted for $48 \mathrm{~h}$.
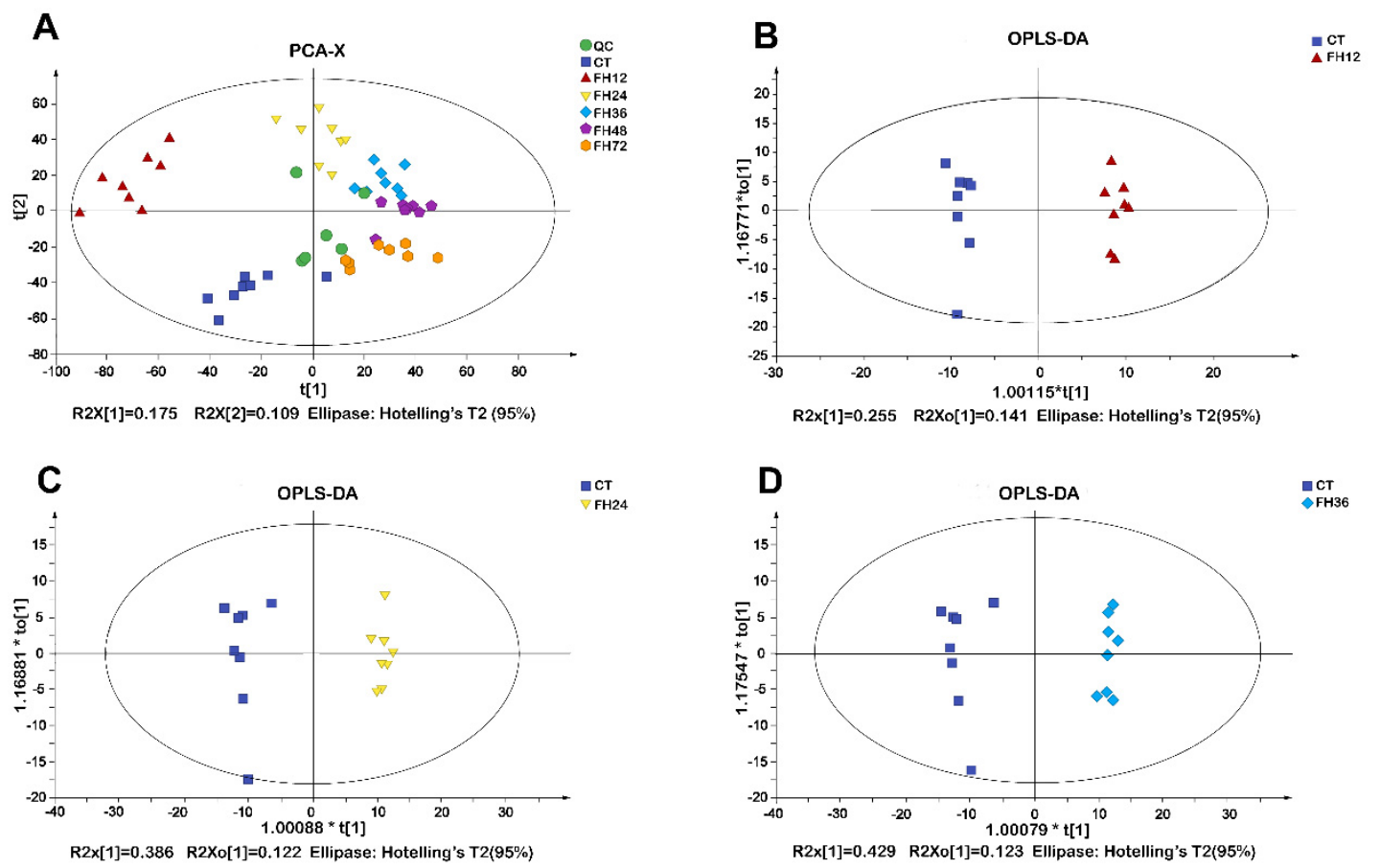

$\square \mathrm{CT}$
$\nabla \mathrm{FH} 24$
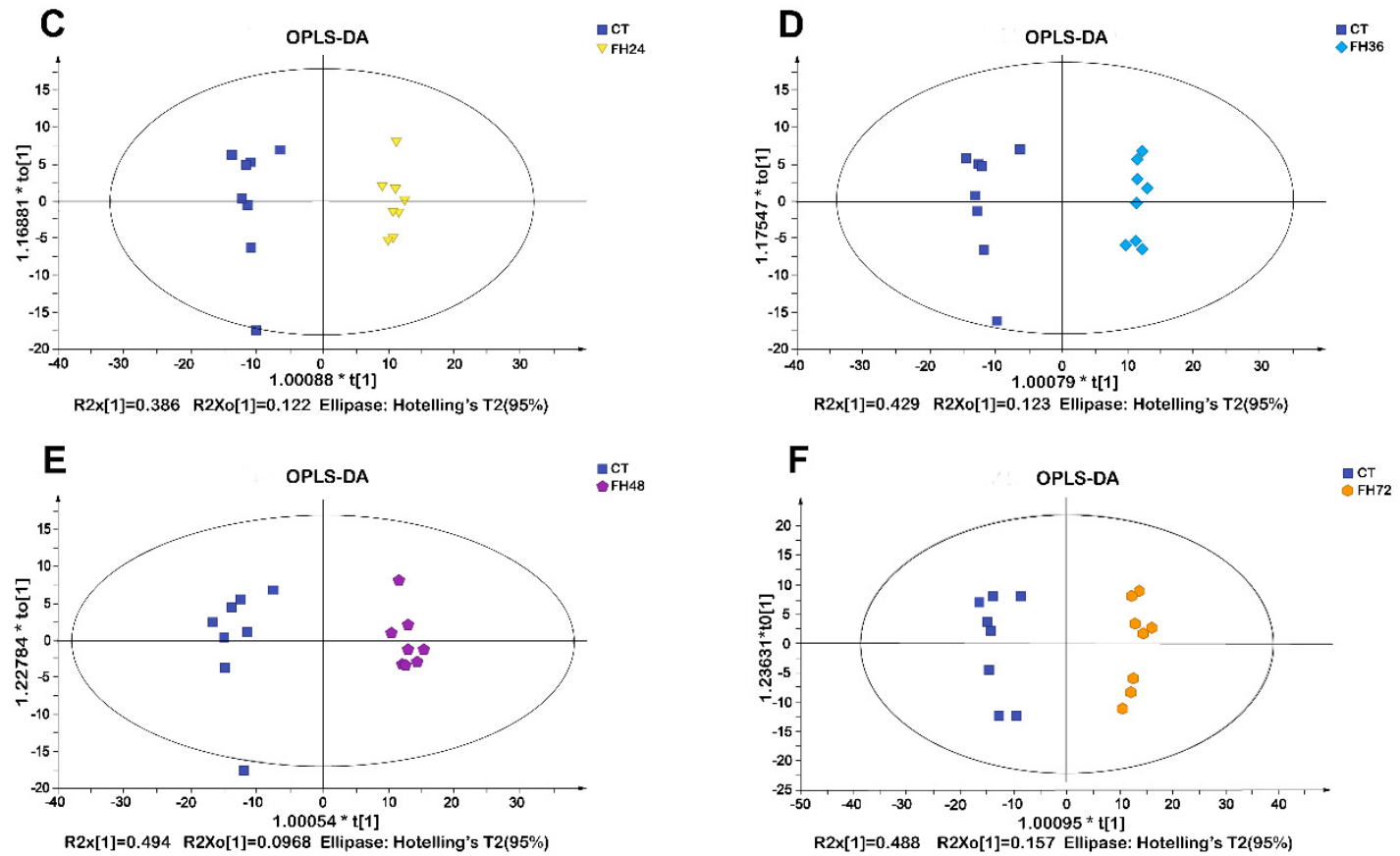

Figure 3. (A)Principal component analysis (PCA) and (B-F) score plots of orthogonal partial least squares discrimination analysis (OPLS-DA) obtained from the non-fasting and fasting groups. CT-birds fed ad libitum; FH12-birds fasted for 12 h; FH24 — birds fasted for 24 h; FH36 — birds fasted for 36 h; FH48_-birds fasted for 48 h. 


\subsection{Serum Metabolic Profiles Changes with Different Durations of Fasting}

Compared with the birds in the $\mathrm{CT}$, the number of changed metabolites decreased within $36 \mathrm{~h}$ of feed deprivation and increased with longer fasting durations (Figure 4B). The serum metabolomics showed the union set of the changed metabolites between different fasting groups and the non-fasting group reached 194 species, the commonly changed species were 23 species (Figure $4 \mathrm{~A}$ and Table S1). The metabolites in the union set were fatty acyl groups (52 species, accounting for 26.8\%), glycerophospholipids (62 species, accounting for $32.0 \%$ ), carboxylic acids and derivatives (13 species, $6.7 \%$ ), steroids and derivatives (7 species, $3.6 \%$ ), organic oxygen compounds ( 7 species, $3.6 \%$ ), organic sulfuric acid and derivatives ( 6 species, $3.1 \%$ ), prenol lipids ( 6 species, $3.1 \%$ ), indoles and derivatives (4 species, 2.1\%), flavonoids (4 species, 2.1\%), and other substances (37 species, 19.1\%, Table S1).

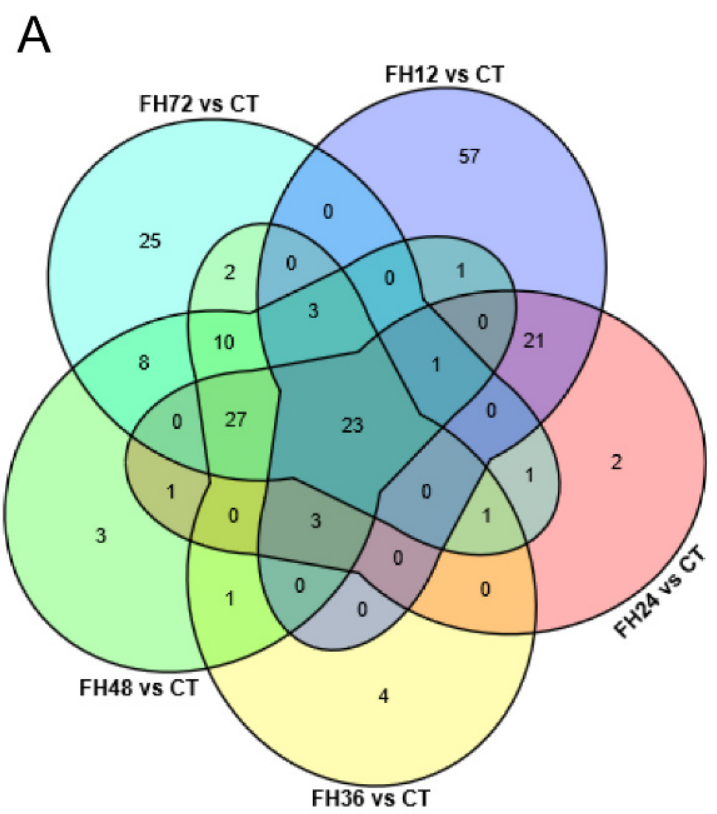

B

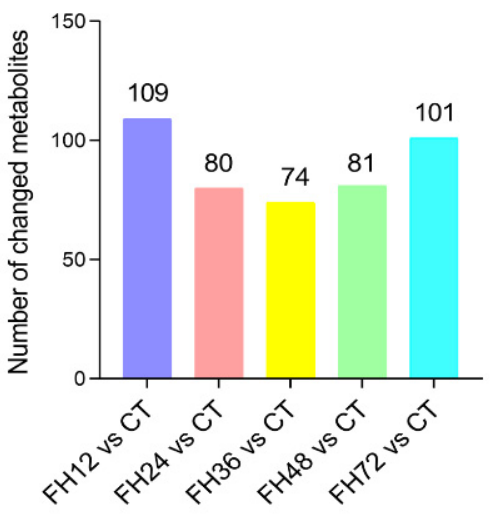

Figure 4. (A) Venn diagram of the changed metabolites for different treatments and (B) the changed metabolite numbers during different fasting durations when compared with the non-fasting group. CT—birds fed ad libitum; FH12 - birds fasted for 12 h; FH24 - birds fasted for 24 h; FH36 - birds fasted for $36 \mathrm{~h}$; FH48- birds fasted for $48 \mathrm{~h}$.

The volcano plots showed that fatty acyls were the most changed metabolites in the birds fasted for $12 \mathrm{~h}$ and glycerophospholipids were the most changed metabolites in the extended fasting (Figure 5). Table S2 shows that $90 \%$ of the fatty acyl substances were significantly changed in the birds fasted for $12 \mathrm{~h}$, of which $91.5 \%$ were increased and $8.5 \%$ were significantly decreased. This effect was gradually lost as the fasting time extended. 
A

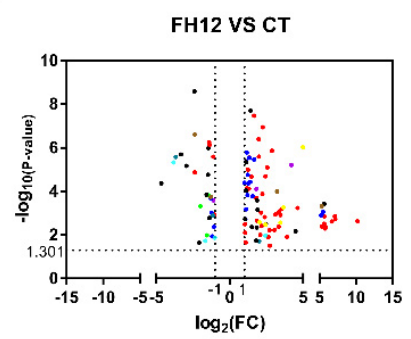

C

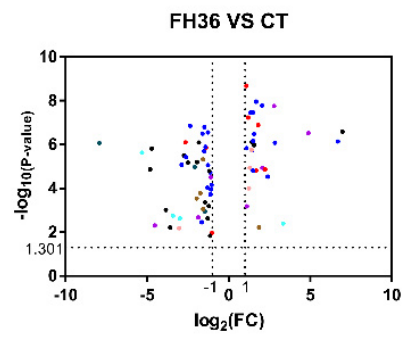

E

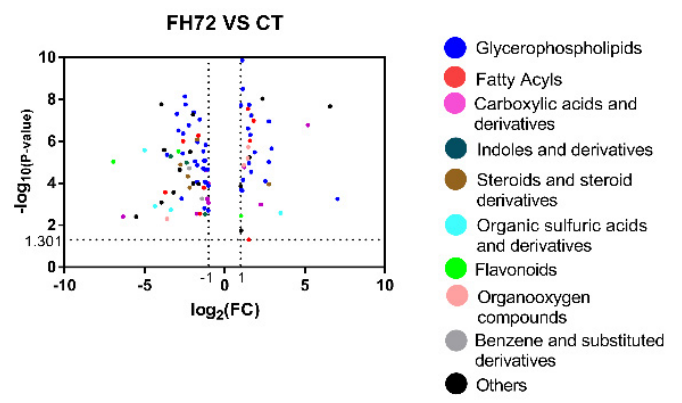

B
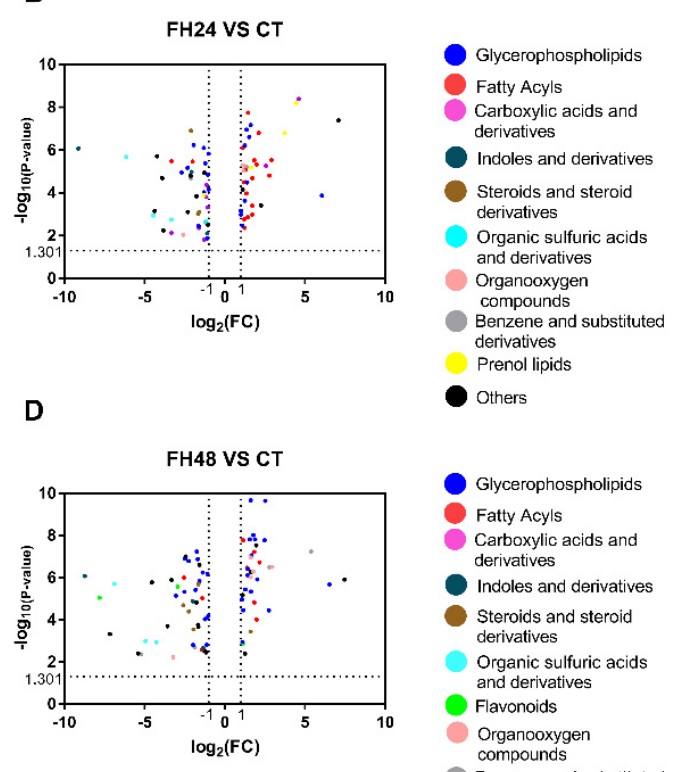

Glycerophospholipids Fatty Acyls Carboxylic acids and

Indoles and derivatives Steroids and steroid derivatives

Organic sulfuric acids and derivatives Flavonoids

Organooxygen
compounds Benzene and substituted derivatives

Others

Figure 5. Volcano plots changed at 12 (A), 24 (B), 36 (C), 48 (D), and $72 \mathrm{~h}$ (E) compared with the non-fasting group.

\subsection{Changes in Serum Fatty Acyl Metabolism with Different Durations of Fasting}

The fatty acyl substances detected in this study mainly consisted of saturated fatty acids (SFA), monoun-saturated fatty acids (MUFA), polyunsaturated fatty acids (PUFA), eicosanoids, and fatty amides (Figure 6A). The level of SFA increased significantly $(p<0.05)$ in FH12 and FH24 and returned to the non-fasting levels in longer fasting durations (Figure 6B). The serum MUFA increased $(p<0.05)$ maximally in FH12, and then decreased to the non-fasting state with prolonged fasting duration (Figure 6C); the serum PUFA level gradually decreased $(p<0.05)$ with the fasting durations extending (Figure 6D). Serum eicosanoid was upregulated in FH12 $(p<0.05)$ and then returned to the non-fasting level in the prolonged fasting durations (Figure 6E and Table S2). It is worth noting that eicosanoids such as the analog of prostaglandin (PG) and leukotriene were significantly increased in the birds of FH12 when compared with the CT ( $p<0.05$, Table S2). The serum lipid amide levels significantly increased $(p<0.05)$ in FH12 and FH24, and then gradually decreased to the non-fasting level in FH72 (Figure 6F). 
A

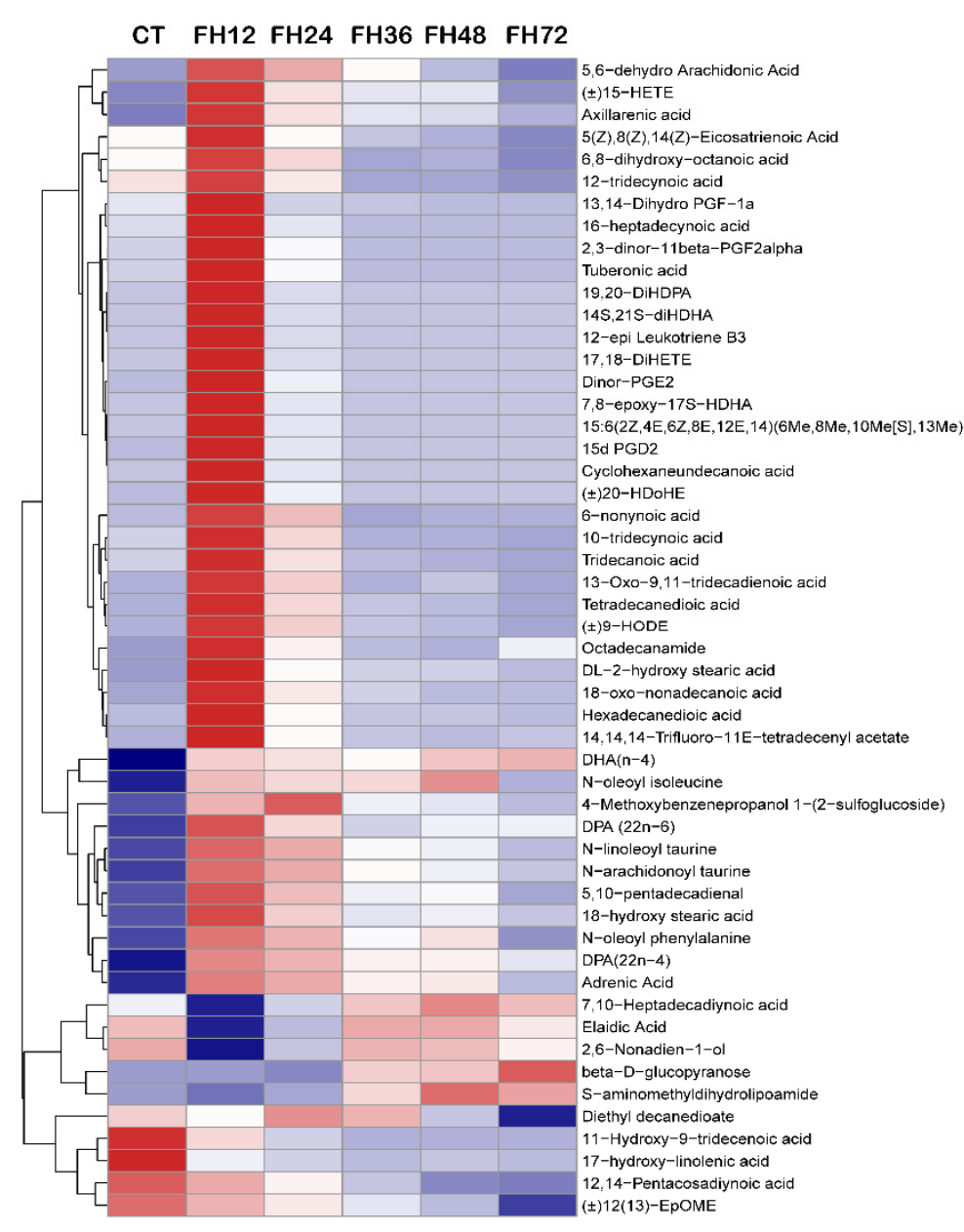

B

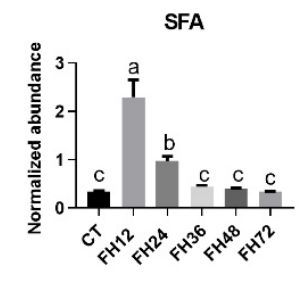

C

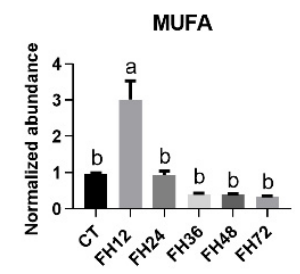

D

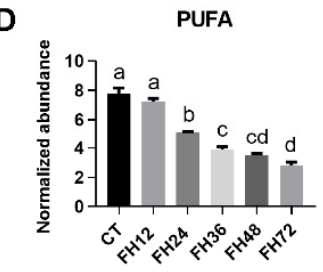

E

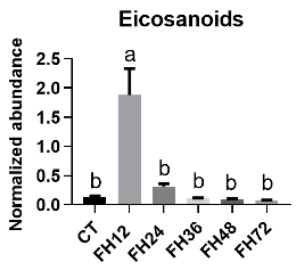

$F$

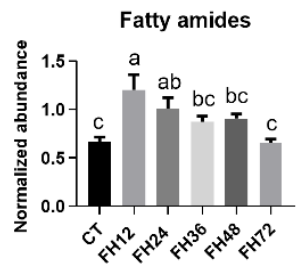

Figure 6. Effect of fasting duration on the serum fatty acyls metabolome. (A) Heatmap of fatty acyls during the different fast durations. Changed serum SFA (B), MUFA (C), PUFA (D), eicosanoids (E), and fatty amides (F) with prolonged fasting duration. Data are analyzed by ANOVA and multiple comparisons using the Duncan correction. Values are means \pm SEM, $n=8$. Labeled means without a common letter are significantly different, $p \leq 0.05$. CT—birds fed ad libitum; FH12-birds fasted for 12 h; FH24 — birds fasted for 24 h; FH36 — birds fasted for 36 h; FH48 — birds fasted for 48 h; SFA—saturated fatty acids; MUFA—monounsaturated fatty acids; PUFA—polyunsaturated fatty acids.

\subsection{Changes in Serum Glycerophospholipids Metabolism with Different Durations of Fasting}

As shown in Figure 7A, the changed serum glycerophospholipids detected in this study were mainly phosphatidylcholine (PC), phosphatidylethanolamine (PE), and their lyso-forms (Lyso-PC and Lyso-PE). The serum PC levels gradually increased with extended fasting durations $(p<0.05$, Figure 7B). The serum Lyso-PC increased with prolonged fasting durations, except in FH72 (Figure 7C); both the serum PE and Lyso-PE levels gradually decreased with the fasting durations extending (all $p<0.05$, Figure 7D,E). 
A
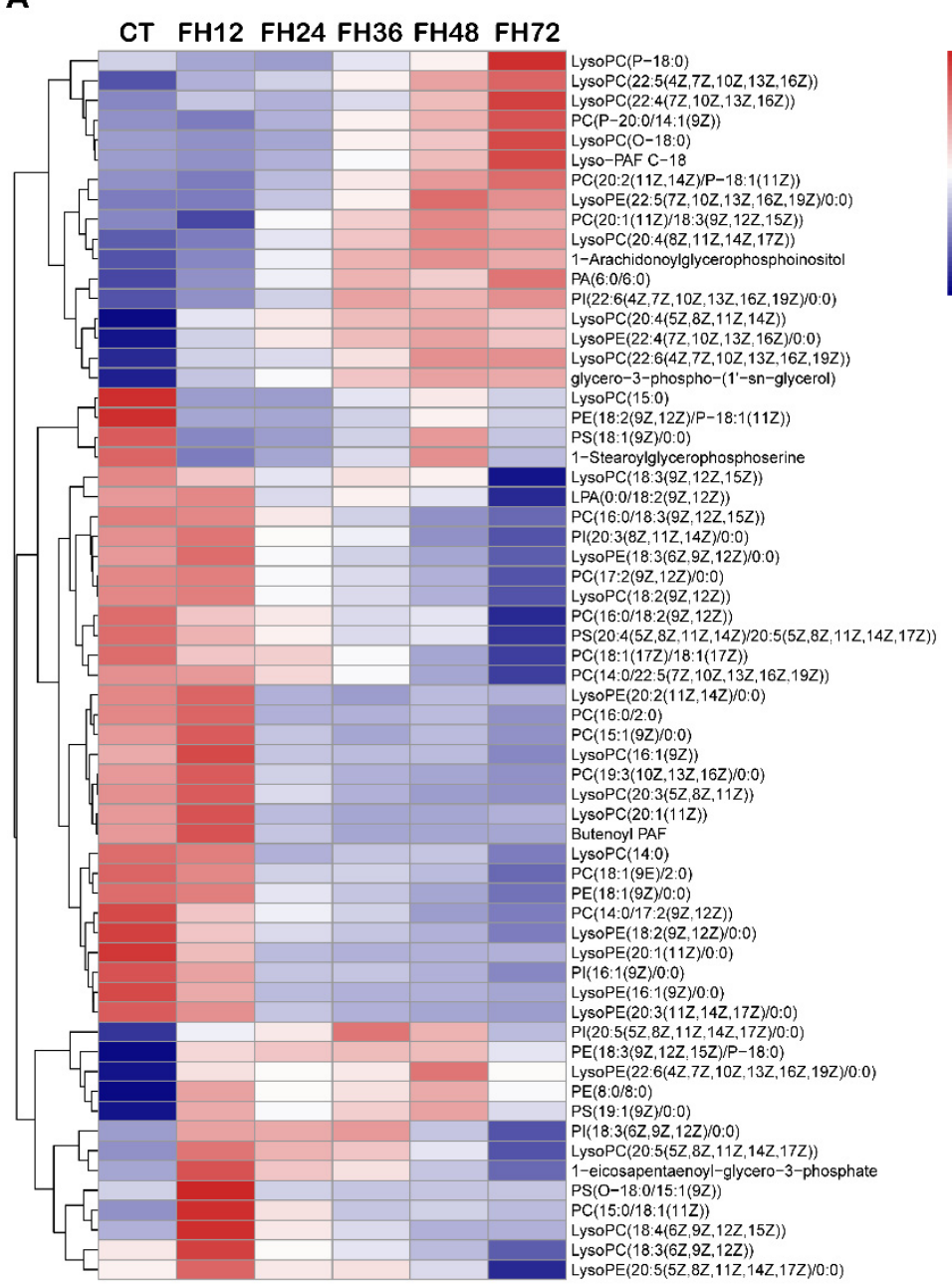

B

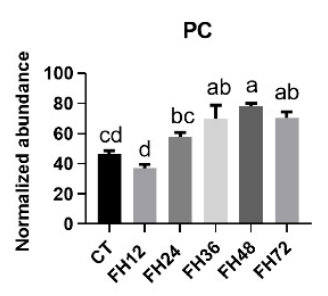

C

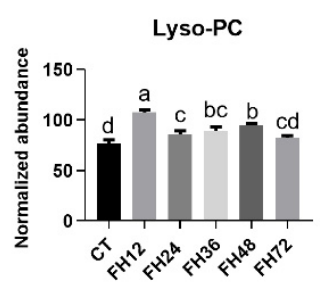

D

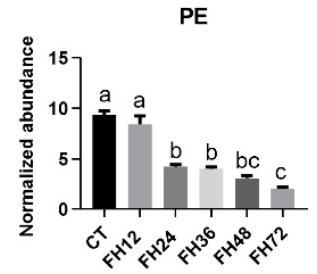

E

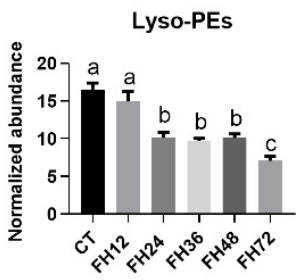

Figure 7. Effect of fasting duration on the serum glycerophospholipid metabolome. (A) Heatmap of glycerophospholipids during the different fasting duration. Changes in PC (B), Lyso-PC (C), PE (D), and Lyso-PE (E) in response to fasting. Data are analyzed by ANOVA and multiple comparisons using the Duncan correction. Values are means \pm SEM, $n=8$. Labeled means without a common letter are significantly different, $p \leq 0.05$. CT—birds fed ad libitum; FH12 - birds fasted for $12 \mathrm{~h}$; FH24-birds fasted for 24 h; FH36 — birds fasted for 36 h; FH48 - birds fasted for 48 h.

\subsection{Changes in Serum Metabolic Pathway with Different Durations of Fasting}

Through the MBRole pathway enrichment analysis, the serum glycerophospholipid metabolism, glycosylphosphatidylinositol anchor biosynthesis (GPI-AB), autophagy, linoleic acid (LA), arachidonic acid (ADA), phenylalanine metabolism, GnRH signaling pathway, and ferroptosis were identified in the fasted birds when compared with the non-fasted (Figure 8). 

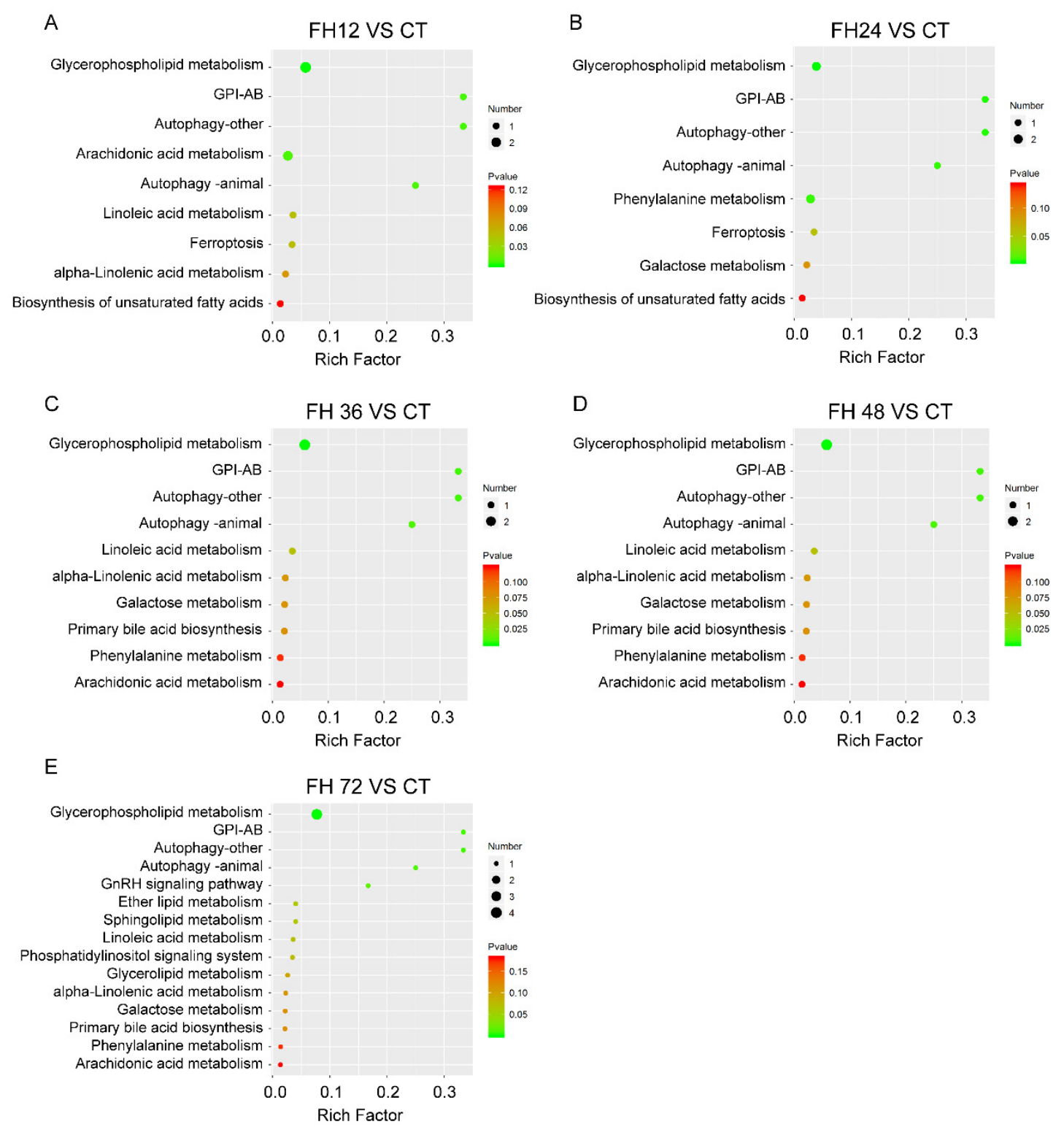

Figure 8. Changed pathways detected in the birds fasted for $12 \mathrm{~h}(\mathbf{A}), 24 \mathrm{~h}(\mathbf{B}), 36 \mathrm{~h}(\mathbf{C}), 48 \mathrm{~h}(\mathbf{D})$, and $72 \mathrm{~h}(\mathrm{E})$ when compared with the birds fed ad libitum. CT—birds fed ad libitum; FH12 — birds fasted for 12 h; FH24-birds fasted for 24 h; FH36 - birds fasted for $36 \mathrm{~h}$; FH48 - birds fasted for $48 \mathrm{~h}$.

We further evaluated the effect of fasting on the host serum metabolic pathways. The abundance of one metabolic pathway was the sum of the abundance of the detected metabolites typically found in that pathway. The results showed that the abundance of serum autophagy, GPI-AB, and ferroptosis were increased significantly during food deprivation, regardless of fasting durations (all $p<0.05$, Figure 9A,C,H). The serum glycerophospholipid metabolic pathway was decreased in the birds fasted longer than $24 \mathrm{~h}(p<0.05$, Figure 9B). Both the serum LA and ADA metabolism were increased (all $p<0.05$ ) in FH12 and then decreased with prolonged fasting (Figure 9D,E). The abundance of the phenylalanine metabolic pathway was downregulated in all of the fasting groups compared with the non-fasting birds $(p<0.05$, Figure 9F). The GnRH signaling pathway was gradually decreased with prolonged fasting durations $(p<0.05$, Figure $9 \mathrm{G})$. 
A

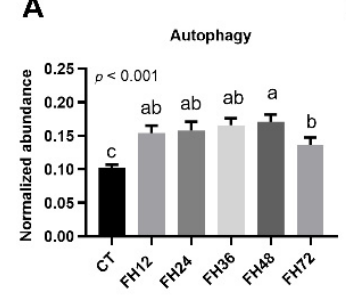

E

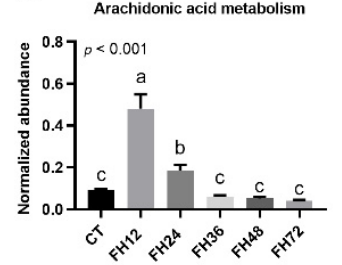

B

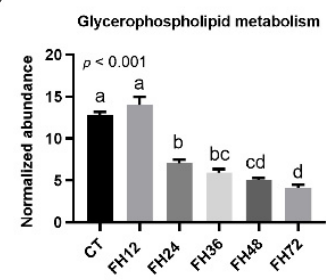

$\mathbf{F}$

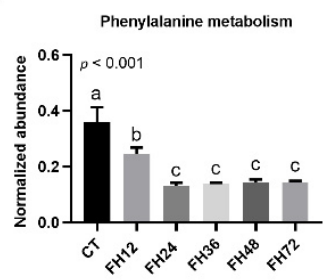

C

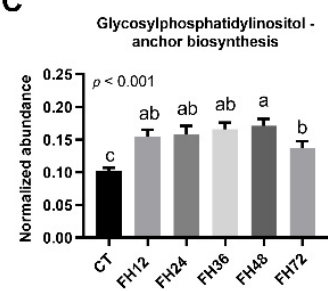

G

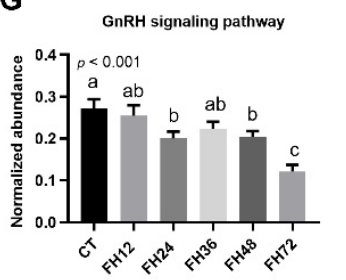

D

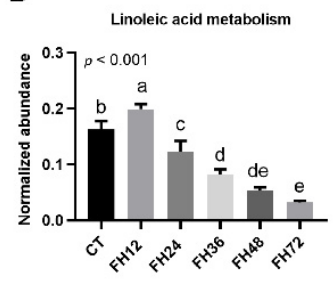

H

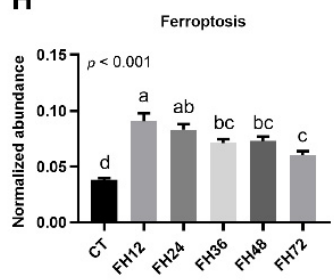

Figure 9. Effects of food withdrawal on the serum metabolome. (A-H) The normalized abundance of metabolite pathways from the control and fasting groups. Data are analyzed by ANOVA and multiple comparisons using the Duncan correction. Values are means $\pm \mathrm{SEM}, n=8$. Labeled means without a common letter are significantly different, $p \leq 0.05$. CT-birds fed ad libitum; FH12 — birds fasted for 12 h; FH24 — birds fasted for 24 h; FH36 — birds fasted for 36 h; FH48_birds fasted for 48 h.

\subsection{Pearson's Correlations between Intestinal Autophagy and Serum PE during Fasting}

The serum autophagy pathway showed a quadratic fitting characteristic with fasting durations $\left(R^{2}=0.380, p<0.001\right)$, which was similar to the intestinal autophagy in response to fasting. It implies that the serum autophagy can monitor the intestinal autophagy level. The phosphatidylethanolamine covalent binding to the Atg protein is essential for autophagy initiation, and its abundance positively regulates autophagy. Here, serum metabolome showed that PE (8:0/8:0) and PE (18:3(9Z,12Z,15Z)/P-18:0) were significantly improved during fasting, even fasted for $12 \mathrm{~h}$. Reversely, PE (18:1(9Z)/0:0) and PE (18:2(9Z,12Z)/P-18:1(11Z)) were significantly decreased compared with the control group (Table S2). Correlation analysis showed that PE (18:3(9Z,12Z,15Z)/P-18:0) and PE (8:0/8:0) were positively correlated with Atg7, whereas PE (18:2(9Z,12Z)/P-18:1(11Z)) and PE (18:1(9Z)/0:0) were inversely correlated with Atg7 (Figure 10). According to the correlation coefficient, serum PE (18:3(9Z,12Z,15Z)/P-18:0) is the best biomarker for monitoring intestinal autophagy.

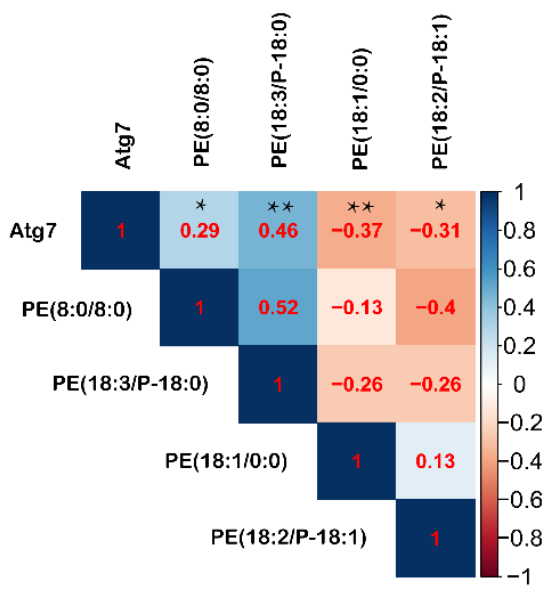

Figure 10. Correlation analysis between intestinal Atg7 and serum PE. Correlation analysis is conducted by the Pearson's correlation. * means $p \leq 0.05,{ }^{* *}$ means $p \leq 0.01$. 


\section{Discussion}

Fasting is widely used in the adjuvant therapy of obesity, inflammation, cardiovascular disease, and so on in humans [1]. In this study, through LC-MS, we identified some altered metabolic pathways at different fasting time points and a potential biomarker in the serum that can predict the intestinal autophagy in chicken.

Autophagy plays an important role in the maintenance of intestinal homeostasis [30]. Generally, autophagy is maintained at a fundamental level in different tissues [31]. Nutritional stress-induced elevated autophagy will harvest the nutrients or damaged organelles for cell survival [32]. Previous work has shown that adult laying hens subjected to 20 days of fasting exhibit large lysosomal autophagic vacuoles in the intestinal epithelial cells and atrophic intestinal villus [33]. It is widely known that Atg7 is a critical autophagy protein that plays an essential role in intestinal integrity [34]. In this study, the genetic expression of Atg7 showed a quadratic response to extended fasting duration, even though previous data indicated an increase in autophagy upon nutrient deprivation $[35,36]$. Our results showed that $12 \mathrm{~h}$ fasting is enough to activate autophagy, and $24 \mathrm{~h}$ of fasting had the highest autophagy process. The reverse shift from its peak could potentially point towards a new energy balance inside the body, because longer fasting reduces heat production in the chicken [37]. Intriguingly, a similar pattern in autophagy was also detected in the serum. Increased autophagy is an efficient metabolic process to alleviate inflammation and cell apoptosis $[11,38]$. It has been reported that fasting reduced inflammatory bowel disease by modulating the microbiota [39]. So, the increased autophagy may provide new evidence for the inflammation pathology. More so, blood cells are a suitable indicator for monitoring autophagic flux [24]. Given that PE covalently binds to the Atg protein during autophagy [40], correlation analysis was applied to the serum PE and intestinal Atg7. We found serum PE (18:3(9Z,12Z,15Z)/P-18:0) is a potential biomarker for intestinal autophagy assessment.

Serum glycerophospholipid was the most detected chemical in the present study. However, the glycerophospholipid metabolism was decreased in the birds fasted for more than $24 \mathrm{~h}$, which is consistent with the results from Maity et al., who reported that starvation decreased glycerophospholipid metabolism in Diporeia [41]. Glycerophospholipid consists of PE, PC, Lyso-PE, and Lyso-PC. It has been reported that Lyso-PC in the plasma is correlated inversely with body mass index [42]. What is more, people refed after food deprivation showed decreased PC and Lyso-PC [43]. Similarly, in the present study, PC and Lyso-PC were increased with fasting. These published data are in agreement with our study. Serum PC is the most abundant phospholipid component in lipoprotein, with the highest levels in the high-density lipoprotein fraction [44]. Increased PC here may imply changes in the lipoprotein metabolism. Serum Lyso-PC, derived from PC by the elimination of one fatty acid by phospholipase A2 and the transesterification by lecithin-cholesterol acyltransferase, accounts for $5-20 \%$ of the total phospholipid and participates in many cellular processes [45]. Recently, it has been reported that increased Lyso-PC is associated with suppressed homocysteine thiolactonase activity [45]. Homocysteine thiolactonase may protect against the vascular injury caused by elevated homocysteine levels by preventing its oxidation to the harmful compound, homocysteine thiolactone [46]. So, the increase in Lyso-PC in the present study may indicate that fasting may damage chicken vascular by suppressed homocysteine thiolactonase activity.

Phosphatidylethanolamine is the second most abundant phospholipid in mammalian cells [44]. By catalyzing phospholipase A2, PE was broken into Lyso-PE [47]. A study has shown that cells cocultured with Lyso-PE can inhibit serum starvation-induced cell apoptosis [48]. The decreased Lyso-PE at prolonged fasting in this study may partly explain the atrophic intestinal villus during fasting [49]. Phosphatidylethanolamine participates in the synthesis of glycosylphosphatidylinositol-anchored protein [50] and mediates cell ferroptosis [51,52]. Glycosylphosphatidylinositol, a widely distributed glycolipid in eukaryotes, is the membrane protein's anchor containing enzymes and receptors [53]. Pantetheinase is one of the glycosylphosphatidylinositol-anchored proteins that hydrolyzes pantetheine 
into cysteamine and pantothenic acid [54], and elevated pantetheinase has been reported in mice fasted for $24 \mathrm{~h}$ when compared with non-fasting mice [55]. Pantothenic acid is a substrate in coenzyme A synthesis that is a necessary cofactor in fatty acid oxidation [56]. So, energy supply during energy deficiency may partly be sourced from increased GPI-AB metabolism in the present study. In turn, serum PE negatively related to GPI-AB and ferroptosis may be attributed to more PE flow into organs and tissues during fasting.

Lipids are the primary energy source for most tissues when glycogen is used up [57]. It was observed that previously birds fasted for 24 and $48 \mathrm{~h}$ showed a decreased concentration of plasma triglyceride and free fatty acid compared with the non-fasted [58]. It has been reported that food withdrawal caused a decrease in overnight fasting serum fatty acid metabolism, including SFA, MUFA, and PUFA in mice [59]. In this study, if we considered the birds fasted for $12 \mathrm{~h}$ as the control group, and the results aligned well with the previous work conducted in mice [60]. Furthermore, our results provide new evidence for recent guidelines that endorse non-fasting profiles for blood sampling [22,60,61].

Fatty acid-related metabolism pathways such as ADA, LA, and GnRH signaling pathways were detected in this study. Linoleic acid, a precursor of ADA [62], was significantly increased in the birds fasted longer than $12 \mathrm{~h}$ and linearly decreased in the birds fasted longer than $12 \mathrm{~h}$. Arachidonic acid can be converted to eicosanoids, such as PG and leukotrienes [62]. In the present study, $12 \mathrm{~h}$ and $24 \mathrm{~h}$ of fasting increased the serum prostaglandin F2, which is similar to previous work conducted in mice $[63,64]$. However, long-term fasting leads to decreased prostaglandin D2, E2, and F2. This can be explained by the long-term fasting-induced deficiency of insulin [65]. In summary, serum ADA and LA metabolism are fasting time-dependent.

In addition, phenylalanine has been regarded as an energy source during food deprivation [66]. The stable level of phenylalanine in birds fasted for $24 \mathrm{~h}$ or longer suggests that the phenylalanine metabolism provides energy within $24 \mathrm{~h}$ of fasting.

\section{Conclusions}

The present study shows that extending the fasting duration from 12 to $72 \mathrm{~h}$ influences the serum metabolic pathways, such as the glycerophospholipid metabolism, GPI-AB, autophagy, ADA metabolism, LA metabolism, ferroptosis, phenylalanine metabolism, and GnRH signaling pathway. Our results also suggest that serum PE (18:3(9Z,12Z,15Z)/P-18:0) is a potential biomarker for intestinal autophagy monitoring, and $24 \mathrm{~h}$ of fasting activates intestinal autophagy well.

Supplementary Materials: The following are available online at https://www.mdpi.com/article/10 .3390/ani11082183/s1. Table S1: Common changed metabolites in different fasting groups; Table S2: Changed serum metabolite concentration after different fasting duration.

Author Contributions: J.Y., Y.G. and Y.W. (Youli Wang) designed and supervised the project. Y.W. (Youli Wang) and Y.X. raised the animals. J.C., X.G., W.W. and Y.W. (Yuqin Wu) collected the samples. Y.W. (Youli Wang) performed the bioinformatics analyses and wrote the manuscript. B.W. and T.M. revised the manuscript. All authors have read and agreed to the published version of the manuscript.

Funding: This work was supported by funding from the National Natural Science Foundation of China (no. 32072752 and no. 31772620 ).

Institutional Review Board Statement: The study was conducted according to the guidelines of the Declaration of Helsinki, and approval by the Laboratory Animal Ethical Commitee of China Agricultural University; protocol number AW04110202-3.

Informed Consent Statement: Informed consent was obtained from all subjects involved in the study.

Data Availability Statement: The data presented in this study are available on request from the corresponding author.

Conflicts of Interest: The authors declare no conflict of interest. 


\section{References}

1. Malinowski, B.; Zalewska, K.; Węsierska, A.; Sokołowska, M.M.; Socha, M.; Liczner, G.; Pawlak-Osińska, K.; Wiciński, M. Intermittent fasting in cardiovascular disorders-An overview. Nutrients 2019, 11, 673. [CrossRef]

2. Bourdillon, A.; Carre, B.; Conan, L.; Duperray, J.; Huyghebaert, G.; Leclercq, B.; Lessire, M.; McNab, J.; Wiseman, J. European reference method for the in vivo determination of metabolisable energy with adult cockerels: Reproducibility, effect of food intake and comparison with individual laboratory methods. Br. Poult. Sci. 1990, 31, 557-565. [CrossRef]

3. Aardsma, M.P.; Mitchell, R.D.; Parsons, C.M. Relative metabolizable energy values for fats and oils in young broilers and adult roosters. Poult. Sci. 2017, 96, 2320-2329. [CrossRef]

4. McNab, J.M.; Blair, J.C. Modified assay for true and apparent metabolisable energy based on tube feeding. Br. Poult. Sci. 1988, 29, 697-707. [CrossRef] [PubMed]

5. Farrell, D.J. Rapid determination of metabolisable energy of foods using cockerels. Br. Poult. Sci. 1978, 19, 303-308. [CrossRef]

6. Inoki, K.; Kim, J.; Guan, K. AMPK and mTOR in cellular energy homeostasis and drug targets. Annu. Rev. Pharmacol. 2012, 52, 381-400. [CrossRef] [PubMed]

7. Mizushima, N. Autophagy: Process and function. Genes Dev. 2007, 21, 2861-2873. [CrossRef] [PubMed]

8. Guo, T.; Nan, Z.; Miao, C.; Jin, X.; Yang, W.; Wang, Z.; Tu, Y.; Bao, H.; Lyu, J.; Zheng, H.; et al. The autophagy-related gene Atg101 in Drosophila regulates both neuron and midgut homeostasis. J. Biol. Chem. 2019, 294, 5666-5676. [CrossRef]

9. Baxt, L.A.; Xavier, R.J. Role of autophagy in the maintenance of intestinal homeostasis. Gastroenterology 2015, 149, 553-562. [CrossRef]

10. Yang, Z.; Klionsky, D.J. Mammalian autophagy: Core molecular machinery and signaling regulation. Curr. Opin. Cell Biol. 2010, 22, 124-131. [CrossRef]

11. Pott, J.; Kabat, A.M.; Maloy, K.J. Intestinal Epithelial Cell Autophagy Is Required to Protect against TNF-Induced Apoptosis during Chronic Colitis in Mice. Cell Host Microbe 2018, 23, 191-202. [CrossRef]

12. Gelino, S.; Chang, J.T.; Kumsta, C.; She, X.; Davis, A.; Nguyen, C.; Panowski, S.; Hansen, M. Intestinal autophagy improves healthspan and longevity in C. elegans during dietary restriction. PLoS Genet. 2016, 12, e1006135.

13. Hay-Koren, A.; Bialik, S.; Levin-Salomon, V.; Kimchi, A. Changes in cIAP2, survivin and BimEL expression characterize the switch from autophagy to apoptosis in prolonged starvation. J. Intern. Med. 2017, 281, 458-470. [CrossRef]

14. Longo, V.D.; Mattson, M.P. Fasting: Molecular mechanisms and clinical applications. Cell Metab. 2014, 19, 181-192. [CrossRef] [PubMed]

15. Wang, S.; Yu, C.; Pan, Y.; Zhou, X.; Xin, R.; Wang, Y.; Ma, W.; Gao, R.; Wang, C.; Wu, Y. Metabolomics analysis of serum from subjects after occupational exposure to acrylamide using UPLC-MS. Mol. Cell Endocrinol. 2017, 444, 67-75. [CrossRef]

16. Lu, Z.; He, X.; Ma, B.; Zhang, L.; Li, J.; Jiang, Y.; Zhou, G.; Gao, F. Serum metabolomics study of nutrient metabolic variations in chronic heat-stressed broilers. Br. J. Nutr. 2018, 119, 771-781. [CrossRef] [PubMed]

17. Papandreou, C.; Bulló, M.; Ruiz-Canela, M.; Dennis, C.; Deik, A.; Wang, D.; Guasch-Ferré, M.; Yu, E.; Razquin, C.; Corella, D.; et al. Plasma metabolites predict both insulin resistance and incident type 2 diabetes: A metabolomics approach within the Prevención con Dieta Mediterránea (PREDIMED) study. Am. J. Clin. Nutr. 2019, 109, 626-634. [CrossRef]

18. Mignon-Grasteau, S.; Beauclercq, S.; Urvoix, S.; Le Bihan-Duval, E. Interest in the serum color as an indirect criterion of selection of digestive efficiency in chickens. Poult. Sci. 2020, 99, 702-707. [CrossRef]

19. Vizcarra, F.R.; Verghese, M.; Vizcarra, J.A. Effect of short- and long-term feed restriction on ghrelin concentrations in turkeys. Poult. Sci. 2018, 97, 2183. [CrossRef] [PubMed]

20. Agostini, P.S.; Dalibard, P.; Mercier, Y.; Van der Aar, P.; Van der Klis, J.D. Comparison of methionine sources around requirement levels using a methionine efficacy method in 0 to 28 day old broilers. Poult. Sci. 2016, 95, 560-569. [CrossRef]

21. Kim, E.J.; Utterback, P.L.; Parsons, C.M. Development of a precision-fed ileal amino acid digestibility assay using 3-week-old broiler chicks. Poult. Sci. 2011, 90, 396-401. [CrossRef] [PubMed]

22. Nordestgaard, B.G.; Langsted, A.; Mora, S.; Kolovou, G.; Baum, H.; Bruckert, E.; Watts, G.F.; Sypniewska, G.; Wiklund, O.; Borén, J.; et al. fasting is not routinely required for determination of a lipid profile: Clinical and laboratory implications including flagging at desirable concentration cut-points-a joint consensus statement from the European Atherosclerosis Society and European Federation of Clinical Chemistry and Laboratory Medicine. Eur. Heart J. 2016, 37, 1944-1958. [PubMed]

23. Teruya, T.; Chaleckis, R.; Takada, J.; Yanagida, M.; Kondoh, H. Diverse metabolic reactions activated during 58-hr fasting are revealed by non-targeted metabolomic analysis of human blood. Sci. Rep. 2019, 9, 854. [CrossRef]

24. Pietrocola, F.; Demont, Y.; Castoldi, F.; Enot, D.; Durand, S.; Semeraro, M.; Baracco, E.E.; Pol, J.; Bravo-San Pedro, J.M.; Bordenave, C.; et al. Metabolic effects of fasting on human and mouse blood in vivo. Autophagy 2017, 13, 567-578. [CrossRef]

25. Beauclercq, S.; Nadal-Desbarats, L.; Hennequet-Antier, C.; Gabriel, I.; Tesseraud, S.; Calenge, F.; Le Bihan-Duval, E.; MignonGrasteau, S. Relationships between digestive efficiency and metabolomic profiles of serum and intestinal contents in chickens. Sci. Rep. 2018, 8, 6678. [CrossRef] [PubMed]

26. Beauclercq, S.; Lefevre, A.; Nadal-Desbarats, L.; Germain, K.; Praud, C.; Emond, P.; Bihan-Duval, E.L.; Mignon-Grasteau, S. Does lipidomic serum analysis support the assessment of digestive efficiency in chickens? Poult. Sci. 2019, 98, 1425-1431. [CrossRef] [PubMed]

27. Psychogios, N.; Hau, D.D.; Peng, J.; Guo, A.C.; Mandal, R.; Bouatra, S.; Sinelnikov, I.; Krishnamurthy, R.; Eisner, R.; Gautam, B.; et al. The human serum metabolome. PLoS ONE 2011, 6, e16957. [CrossRef] [PubMed] 
28. Mountzouris, K.C.; Tsitrsikos, P.; Palamidi, I.; Arvaniti, A.; Mohnl, M.; Schatzmayr, G.; Fegeros, K. Effects of probiotic inclusion levels in broiler nutrition on growth performance, nutrient digestibility, plasma immunoglobulins, and cecal microflora composition. Poult. Sci. 2010, 89, 58-67. [CrossRef]

29. Wang, Y.; Yin, X.; Yin, D.; Lei, Z.; Mahmood, T.; Yuan, J. Antioxidant response and bioavailability of methionine hydroxy analog relative to DL-methionine in broiler chickens. Anim. Nutr. 2019, 5, 241-247. [CrossRef]

30. Haq, S.; Grondin, J.; Banskota, S.; Khan, W.I. Autophagy: Roles in intestinal mucosal homeostasis and inflammation. J. Biomed. Sci. 2019, 26, 19. [CrossRef] [PubMed]

31. Piekarski, A.; Khaldi, S.; Greene, E.; Lassiter, K.; Mason, J.G.; Anthony, N.; Bottje, W.; Dridi, S. Tissue distribution, gender- and genotype-dependent expression of autophagy-related genes in avian species. PLoS ONE 2014, 9, e112449. [CrossRef]

32. Kadowaki, M.; Razaul Karim, M.; Carpi, A.; Miotto, G. Nutrient control of macroautophagy in mammalian cells. Mol. Asp. Med. 2006, 27, 426-443. [CrossRef]

33. Yamauchi, K.; Kamisoyama, H.; Isshiki, Y. Effects of fasting and refeeding on structures of the intestinal villi and epithelial cells in White Leghorn hens. Br. Poult. Sci. 1996, 37, 909-921. [CrossRef] [PubMed]

34. Ra, E.A.; Lee, T.A.; Won Kim, S.; Park, A.; Choi, H.J.; Jang, I.; Kang, S.; Hee Cheon, J.; Cho, J.W.; Eun Lee, J.; et al. TRIM31 promotes Atg5/Atg7-independent autophagy in intestinal cells. Nat. Commun. 2016, 7, 11726. [CrossRef] [PubMed]

35. He, L.; Zhang, J.; Zhao, J.; Ma, N.; Kim, S.W.; Qiao, S.; Ma, X. Autophagy: The last defense against cellular nutritional stress. Adv. Nutr. 2018, 9, 493-504. [CrossRef]

36. Yang, Z.; Huang, C.; Wu, Y.; Chen, B.; Zhang, W.; Zhang, J. Autophagy protects the blood-brain barrier through regulating the dynamic of claudin-5 in short-term starvation. Front. Physiol. 2019, 10. [CrossRef]

37. Noblet, J.; Dubois, S.; Lasnier, J.; Warpechowski, M.; Dimon, P.; Carré, B.; van Milgen, J.; Labussière, E. Fasting heat production and metabolic BW in group-housed broilers. Animal 2015, 9, 1138-1144. [CrossRef]

38. Cosin-Roger, J.; Simmen, S.; Melhem, H.; Atrott, K.; Frey-Wagner, I.; Hausmann, M.; de Vallière, C.; Spalinger, M.R.; Spielmann, P.; Wenger, R.H.; et al. Hypoxia ameliorates intestinal inflammation through NLRP3/mTOR downregulation and autophagy activation. Nat. Commun. 2017, 8, 98. [CrossRef]

39. Rangan, P.; Choi, I.; Wei, M.; Navarrete, G.; Guen, E.; Brandhorst, S.; Enyati, N.; Pasia, G.; Maesincee, D.; Ocon, V.; et al. Fasting-mimicking diet modulates microbiota and promotes intestinal regeneration to reduce inflammatory bowel disease pathology. Cell Rep. 2019, 26, 2704-2719. [CrossRef] [PubMed]

40. Hanada, T.; Satomi, Y.; Takao, T.; Ohsumi, Y. The amino-terminal region of Atg3 is essential for association with phosphatidylethanolamine in Atg8 lipidation. FEBS Lett. 2009, 583, 1078-1083. [CrossRef] [PubMed]

41. Maity, S.; Jannasch, A.; Adamec, J.; Nalepa, T.; Höök, T.O.; Sepúlveda, M.S. Starvation causes disturbance in amino acid and fatty acid metabolism in Diporeia. Comp. Biochem. Physiol. B Biochem. Mol. Biol. 2012, 161, 348-355. [CrossRef]

42. Weir, J.M.; Wong, G.; Barlow, C.K.; Greeve, M.A.; Kowalczyk, A.; Almasy, L.; Comuzzie, A.G.; Mahaney, M.C.; Jowett, J.B.M.; Shaw, J.; et al. Plasma lipid profiling in a large population-based cohort. J. Lipid Res. 2013, 54, 2898-2908.

43. Shrestha, A.; Müllner, E.; Poutanen, K.; Mykkänen, H.; Moazzami, A.A. Metabolic changes in serum metabolome in response to a meal. Eur. J. Nutr. 2017, 56, 671-681. [CrossRef] [PubMed]

44. Dashti, M.; Kulik, W.; Hoek, F.; Veerman, E.C.; Peppelenbosch, M.P.; Rezaee, F. A phospholipidomic analysis of all defined human plasma lipoproteins. Sci. Rep. 2011, 1, 139. [CrossRef] [PubMed]

45. Sonoki, K.; Iwase, M.; Sasaki, N.; Ohdo, S.; Higuchi, S.; Matsuyama, N.; Iida, M. Relations of lysophosphatidylcholine in low-density lipoprotein with serum lipoprotein-associated phospholipase A2, paraoxonase and homocysteine thiolactonase activities in patients with type 2 diabetes mellitus. Diabetes Res. Clin. Pract. 2009, 86, 117-123. [CrossRef] [PubMed]

46. Daly, C.; Fitzgerald, A.P.; O'Callaghan, P.; Collins, P.; Cooney, M.T.; Graham, I.M. Homocysteine increases the risk associated with hyperlipidaemia. Eur. J. Cardiovasc. Prev. Rehabil. 2009, 16, 150-155. [CrossRef]

47. Tepperman, B.L.; Soper, B.D. The role of phospholipase A2 in calcium-ionophore-mediated injury to rat gastric mucosal cells. Dig. Dis. Sci. 1999, 44, 494-502. [CrossRef]

48. Nishina, A.; Kimura, H.; Sekiguchi, A.; Fukumoto, R.; Nakajima, S.; Furukawa, S. Lysophosphatidylethanolamine in Grifola frondosa as a neurotrophic activator via activation of MAPK. J. Lipid Res. 2006, 47, 1434-1443. [CrossRef] [PubMed]

49. Uchida, H.; Nakajima, Y.; Ohtake, K.; Ito, J.; Morita, M.; Kamimura, A.; Kobayashi, J. Protective effects of oral glutathione on fasting-induced intestinal atrophy through oxidative stress. World J. Gastroenterol. 2017, 23, 6650-6664. [CrossRef] [PubMed]

50. Patel, D.; Witt, S.N. Ethanolamine and phosphatidylethanolamine: Partners in health and disease. Oxidative Med. Cell. Longev. 2017, 2017, 1-18. [CrossRef] [PubMed]

51. Kagan, V.E.; Mao, G.; Qu, F.; Angeli, J.P.F.; Doll, S.; Croix, C.S.; Dar, H.H.; Liu, B.; Tyurin, V.A.; Ritov, V.B.; et al. Oxidized arachidonic and adrenic PEs navigate cells to ferroptosis. Nat. Chem. Biol. 2017, 13, 81-90. [CrossRef]

52. Doll, S.; Proneth, B.; Tyurina, Y.Y.; Panzilius, E.; Kobayashi, S.; Ingold, I.; Irmler, M.; Beckers, J.; Aichler, M.; Walch, A.; et al. ACSL4 dictates ferroptosis sensitivity by shaping cellular lipid composition. Nat. Chem. Biol. 2017, 13, 91-98. [CrossRef]

53. Consortium, T.U. UniProt: A hub for protein information. Nucleic Acids Res. 2015, 43, D204-D212. [CrossRef]

54. Pitari, G.; Malergue, F.; Martin, F.; Philippe, J.M.; Massucci, M.T.; Chabret, C.; Maras, B.; Dupre, S.; Naquet, P.; Galland, F. Pantetheinase activity of membrane-bound Vanin-1: Lack of free cysteamine in tissues of Vanin-1 deficient mice. FEBS Lett. 2000, 483, 149-154. [CrossRef] 
55. Lin, Y.; Gao, Y.; Ma, Z.; Li, Z.; Tang, C.; Qin, X.; Zhang, Z.; Wang, G.; Du, L.; Li, M. Bioluminescent probe for detection of starvation-induced pantetheinase upregulation. Anal. Chem. 2018, 90, 9545-9550. [CrossRef]

56. Daugherty, M.; Polanuyer, B.; Farrell, M.; Scholle, M.; Lykidis, A.; de Crécy-Lagard, V.; Osterman, A. Complete reconstitution of the human coenzyme A biosynthetic pathway via comparative genomics. J. Biol. Chem. 2002, 277, 21431-21439. [CrossRef] [PubMed]

57. Cahill, J.G.F. Fuel metabolism in starvation. Annu. Rev. Nutr. 2006, 26, 1-22. [CrossRef] [PubMed]

58. Fang, X.; Zhu, X.; Chen, S.; Zhang, Z.; Zeng, Q.; Deng, L.; Peng, J.; Yu, J.; Wang, L.; Wang, S.; et al. Differential gene expression pattern in hypothalamus of chickens during fasting-induced metabolic reprogramming: Functions of glucose and lipid metabolism in the feed intake of chickens. Poult. Sci. 2014, 93, 2841-2854. [CrossRef] [PubMed]

59. Zheng, X.; Zhou, K.; Zhang, Y.; Han, X.; Zhao, A.; Liu, J.; Qu, C.; Ge, K.; Huang, F.; Hernandez, B.; et al. Food withdrawal alters the gut microbiota and metabolome in mice. FASEB J. 2018, 32, 4878-4888. [CrossRef] [PubMed]

60. Nordestgaard, B.G. A test in context: Lipid profile, fasting versus non-fasting. J. Am. Coll. Cardiol. 2017, 70, 1637-1646. [CrossRef]

61. Langsted, A.; Nordestgaard, B.G. Nonfasting versus fasting lipid profile for cardiovascular risk prediction. Pathology 2019, 51, 131-141. [CrossRef] [PubMed]

62. Whelan, J.; Fritsche, K. Linoleic Acid. Adv. Nutr. 2013, 4, 311-312. [CrossRef]

63. Yan, S.; Zhang, Q.; Zhong, X.; Tang, J.; Wang, Y.; Yu, J.; Zhou, Y.; Zhang, J.; Guo, F.; Liu, Y.; et al. I prostanoid receptor-mediated inflammatory pathway promotes hepatic gluconeogenesis through activation of PKA and inhibition of AKT. Diabetes 2014, 63, 2911-2923. [CrossRef] [PubMed]

64. Wang, Y.; Yan, S.; Xiao, B.; Zuo, S.; Zhang, Q.; Chen, G.; Yu, Y.; Chen, D.; Liu, Q.; Liu, Y.; et al. Prostaglandin F2alpha facilitates hepatic glucose production through CaMKIIgamma/p38/FOXO1 signaling pathway in fasting and obesity. Diabetes 2018, 67, 1748-1760. [CrossRef]

65. Arisaka, M.; Arisaka, O.; Fukuda, Y.; Yamashiro, Y. Prostaglandin metabolism in children with diabetes mellitus. I. plasma prostaglandin E2, F2 $\alpha$, TXB2, and serum fatty acid levels. J. Pediatr. Gastr. Nutr. 1986, 5, 878-882. [CrossRef] [PubMed]

66. Pan, Y.H.; Zhang, Y.; Cui, J.; Liu, Y.; McAllan, B.M.; Liao, C.C.; Zhang, S. Adaptation of phenylalanine and tyrosine catabolic pathway to hibernation in bats. PLoS ONE 2013, 8, e62039. [CrossRef] [PubMed] 